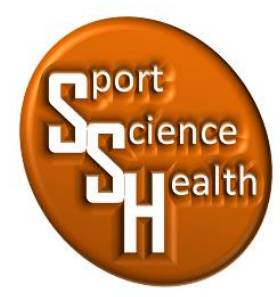

ISSN 2715-3886

\title{
Pengaruh Latihan Kelincahan Dribble Bentuk $T$-Drill Langsung dan Tidak Langsung terhadap Peningkatan Kemampuan Keterampilan Dribble Peserta Kegiatan Ekstrakurikuler Bolabasket SMP
}

\author{
Khilliyatuz Zahrina ${ }^{1 *}$, Siti Nurrochmah ${ }^{2}$ \\ 1,2Jurusan Pendidikan Jasmani, Kesehatan dan Rekreasi, Fakultas IImu Keolahragaan, \\ Universitas Negeri Malang, Jalan Semarang No 5, Malang, Jawa Timur, 65145, Indonesia \\ *Penulis koresponden: aylakhilya@gmail.com, 085232443251
}

Artikel diterima: 9 Januari 2020; direvisi: 23 Januari 2021; disetujui: 26 Januari 2021

\begin{abstract}
The purpose of this study was to study and obtain information on the effect of direct and indirect T-Drill dribble agility training on improving the dribbling ability of basketball balls. This study used an experimental design in the form of Randomized Control Groub Pre-test-Post-test Design. The population in this study were 34 participants in the extracurricular basketball activities at SMP Negeri 1 Prigen. Sampling using systematic proportional random sampling technique with a percentage of $90 \%$ of 36 participants, so that the number of samples 34 participants. To determine the effect of direct and indirect form of T-Drill dribble training on improving the ability of basketball dribble skills obtained by Fcount 76.73344 more than Ftable $\alpha$ equal to 0.054 .149097 , meaning there is a difference related to the test of dribble skills between before the test T-Drill form's direct and indirect form of agility dribble skills. The results of the F-test analysis were continued by calculating the advanced test of the Leat Significance Difference (LSD) form, the results of the mean data for all groups were 5.61707 and the LSD coefficient was 0.051 .652 . Giving direct T-Drill dribble drills is better than giving indirect T-Drill drills.
\end{abstract}

Keyword: training, agility, basketball dribble training

\begin{abstract}
Abstrak: Tujuan penelitian ini adalah untuk mengkaji dan memperoleh informasi pengaruh latihan kelincahan dribble T-Drill langsung dan tidak langsung terhadap peningkatan kemampuan dribble bolabasket. Penelitian ini menggunakan rancangan eksperimental bentuk Randomized Control Groub Pre test-Post test Design. Populasi dalam penelitian ini adalah peserta kegiatan ektrakurikuler bolabasket SMP Negeri 1 Prigen yang berjumlah 34 orang coba. Pengambilan sampel menggunakan teknik systematic porposive random sampling dengan presentase sebesar $90 \%$ dari 36 peserta, sehingga jumlah sampel 34 peserta. Untuk mengetahui pengaruh latihan dribble bentuk $T$-Drill langsung dan tidak langsung terhadap peningkatan kemampuan keterampilan dribble bolabasket diperoleh sebesar $F_{\text {hitung }} 76,73344$ lebih dari $F_{\text {tabel a sama dengan } 0,05} 4,149097$, berarti ada perbedaan yang berhubungan tes kemampuan keterampilan dribble antara sebelum tes kemampuan keterampilan dribble kelincahan bentuk $T$ Drill langsung dan tidak langsung. Hasil analisis uji $\mathrm{F}$ dilanjutkan dengan menghitung uji lanjut bentuk Leat Significance Difference (LSD), hasil mean data seluruh kelompok diperoleh 5,61707 dan koefisien $\operatorname{LSD}_{0,05}$ 1,652. Pemberian latihan dribble $T$-Drill langsung lebih baik dibandingkan dengan pemberian latihan $T$-Drill tidak langsung.
\end{abstract}

Kata kunci: latihan, kelincahan, latihan dribble bolabasket 


\section{PENDAHULUAN}

Olahraga merupakan salah satu instrumen yang dimiliki negara dalam rangka untuk mencapai suatu kejayaan. Sehingga, dalam posisi yang strategis ini olahraga dapat dijadikan soft power bagi suatu negara, itu sebabnya olahraga dijadikan sebagai aset negara untuk meningkatkan kualitas masa depan, sehingga oleh pihak pemerintah olahraga digarap secara serius, yang terpadu dalam pendidikan, kajian lintas bidang maupun sudah memanfaatkan sport sciene serta memilik koordinasi yang jelas. Olahraga adalah upaya manusia menuju hidup sehat. Ada beberapa perumusan tentang pengertian olahraga yang pada hakekatnya mempunyai pengertian yang sama yaitu bahwa olahraga mengandung unsur gerak sebagai prinsip dasar dan bertujuan mengolah manusia seutuhnya (Sciences, 2014; Sport England, 2015).

Pendidikan jasmani bertujuan membentuk pribadi seutuhnya yang mencakup kemampuannya dan daya tahan fisik, keterampilan motorik, pertumbuhan kecerdasan, dan pembentukan watak (Department for Education, 2013; Education et al., 2016; Society of Health and Physical Educators America, 2016). Dalam proses pembelajaran pendidikan jasmani guru harus mengajarkan berbagai keterampilan gerak dasar, teknik serta strategi permainan dan olahraga. Tercantum pada Standar Kompetensi dan Kompetensi Dasar dalam standar isi yang dibuat oleh Badan Standar Nasional Pendidikan materi pada mata pelajaran pendidikan jasmani, olahraga, dan kesehatan di dalamnya terdapat olahraga dan permainan bola besar, olahraga dan permainan bola kecil, atletik dan keterampilan bela diri serta aktivitas lainnya. Dalam olahraga permainan bola besar terdapat materi permainan bolavoli yang menjadi pilihan utama para guru untuk diajarkan ke pesrta didik, karena permainan bolavoli sarana dan prasarananya mudah untuk dimodifikasi, selain sarana dan prasarana yang dapat dimodifikasi permainannya juga dapat dimodifikasi sesederhana mungkin, dan tingkat cidera peserta didik juga sangat kecil karena tidak terjadi kontak fisik secara langsung dengan lawan.

Peraturan Menteri Pendidikan dan Kebudayaan Republik Indonesia Nomor 81A Tahun 2013 tentang Implementasi Kurikulum Pedoman Kegiatan Ekstrakurikuler menjelaskan bahwa "ekstrakurikuler adalah kegiatan pendidikan yang dilakukan oleh peserta didik di luar jam belajar kurikulum standar sebagai dengan tujuan untuk mengembangkan kepribadian, bakat, minat, dan kemampuan peserta didik yang lebih luas atau di luar minat yang dikembangkan oleh kurikulum". Berdasarkan definisi tersebut kegiatan di sekolah ataupun di luar sekolah yang berkaitan dengan tugas belajar suatu mata pelajaran bukanlah suatu kegiatan ekstrakurikuler. Kegiatan ekstrakurikuler merupakan program wajib yang harus diikuti setiap peserta didik, kecuali bagi peserta didik yang tidak memungkinkan kondisinya.

Permainan bolabasket dimainkan oleh dua regu yang masing-masing regu dimainkan oleh 5 orang pemain. Setiap regu berusaha memasukkan bola sebanyak-banyaknya kekeranjang lawan dan mencegah pihak lawan memasukkan bola ke dalam keranjangnya sendiri. Bola boleh dilemparkan, dipantul-pantulkan, digelindingkan, didorong sesuai dengan peraturan permainan (Adiningtyas et al., 2020; Rohmatunisha et al., 2020)." Dribble dalam bolabasket adalah salah satu teknik dasar bola basket yang pertama diperkenalkan kepada para siswa, karena keterampilan ini sangat penting bagi setiap pemain yang terlibat dalam pertandingan bola basket (Puente et al., 2017; Trojian et al., 2013). Sedangkan pendapat lainnya menyampaikan bahwa menggiring bola adalah membawa bola lari ke segala arah sesuai dengan peraturan yang ada. Seorang pemain diperbolehkan membawa bola lebih dari satu langkah asalkan bola dipantulkan ke lantai, baik berjalan maupun berlari. Menggiring bola harus menggunakan satu tangan. Kegunaan menggiring bola adalah mencari peluang serangan, menerobos pertahanan lawan, ataupun memperlambat tempo permainan (French \& Thomas, 2016; Stöckel \& Vater, 2014). Jadi dapat disimpulkan bahwa menggiring bola (dribble) bolabasket adalah kemampuan teknik dasar seorang pemain memindahkan bola menggunakan tangan dengan secepat-cepatnya sebagai bentuk tujuan untuk mengadakan serangan balik, melewati lawan dan mengatur tempo permainan serta untuk mencetak angka sebanyak-banyaknya tanpa kehilangan keseimbangan.

Agar siswa mampu melakukan dribble dengan baik, maka yang penting untuk diperhatikan adalah melakukan latihan untuk meningkatkan kemampuan kondisi fisik seperti kekuatan, kecepatan, daya ledak, daya tahan dan kelincahan. Diantara unsur-unsur kondisi fisik tersebut peneliti tertarik mengkaji pada unsur kondisi fisik kelincahan. Karena kelincahan dibutuhkan untuk mengubah arah gerakan tanpa mengurangi gerakan.

Kelincahan merupakan salah satu unsur pada pengkuran kemampun umum bergerak. Pengukuran pada tes kemampuan umum bergerak melibatkan unsur lari, lompat, panjat, dan lempar. Butir-butir tes tersebut sebagai tes berangkai untuk mengukur kemampuan umum bergerak. Untuk memudahkan proses penggolongan dan 
penilaian prestasi, maka telah disusun tes berangkai kemampuan umum bergerak yang melibatkan unsur daya ledak, kecepatan, kelincahan, kekuatan, keseimbangan dan kelentukan (Eom et al., 2014; Mehdizadeh et al., 2015). Kelincahan (agility) adalah kemampuan untuk mengubah arah dengan cepat dan tepat pada waktu bergerak tanpa kehilangan keseimbangan dan kesadaran akan posisi tubuh (McInnes et al., 2014; Stovern et al., 2019).

Untuk mencapai peningkatan prestasi olahraga yang tinggi diperlukan suatu proses latihan, waktu yang cukup, dan didukung oleh berbagai faktor. Latihan menurut para pakar adalah proses melakukan kegiatan olahraga yang dilakukan berdasarkan program latihan yang disusun secara sistematis, bertujuan untuk meningkatkan kemampuan atlet dalam upaya mencapai prestasi yang semaksimal mungkin, terutama dilaksanakan untuk persiapan menghadapi suatu pertandingan (Hayashi, 2016; Markula, 2015; Winslade \& Wright, 2019). Dengan demikian dapat disimpulkan bahwa saat melakukan kelincahan membutuhkan komponen-komponen sebagai penunjang keberhasilan gerakan kelincahan yang baik. Pada saat melakukan kelincahan dibutuhkan adanya latihan fisik, latihan fisik yang baik adalah latihan fisik yang dilakukan secara runtut dan sistematis. Tanpa adanya latihan fisik maka latihan tidak akan berhasil dengan baik.

Latihan T-Drill merupakan salah satu bentuk latihan dari kelincahan. Tujuan melakukan tes kelincahan T-drill adalah untuk meningkatan kelincahan, pengondisian, fleksibilitas, dan kekuatan. Keuntungan latihan agility TDrill yaitu gerakannya yang berlari secara lurus dan merubah arah secara cepat dengan bergeser ke samping kanan dan kiri (Arshi et al., 2015; W. Kusnanik et al., 2019).

Berdasarkan analisis kebutuhan berupa angket dari 21 siswa peserta kegiatan ekstrakurikuler bolabasket $65 \%$ menyukai latihan kelincahan, $80 \%$ sangat membutuhkan latihan kelincahan untuk bergerak merubah arah melewati lawan, 90\% setuju diberikannya latihan kelincahan secara sistematis, dan sebanyak $80 \%$ setuju diberi latihan $T$-Drill. Selain itu, peneliti juga melakukan observasi awal melalaui tes awal menggunakan dribble T-Drill untuk mengetahui tingkat kelincahan dari 21 peserta kegiatan ekstrakurikuler bolabasket SMPN 1 Prigen diperoleh hasil, 20\% atau 5 siswa memiiki kemampuan kelincahan good, 20\% atau 5 siswa memiliki kemampuan kelincahan average, 50\% atau 8 siswa memiliki kemampuan kelincahan fair dan $10 \%$ atau 3 siswa memiliki kemampuan kelincahan poor. Jadi dapat disimpulkan bahwa peserta kegiatan ekstrakurikuler bolabasket SMPN 1 Prigen sangat membutuhkan latihan kelincahan secara sistematis.

Sebagai tindak lanjut dari hasil penelitian yang sebelumnya serta dari hasil observasi penulis tentang permasalahan kondisi kelincahan pada permainan bolabasket khususnya ketika melakukan keterampilan dribble, masalah tersebut menarik untuk dikaji. Penulis tertarik untuk melakukan penelitian tentang kelincahan dan kemampuan dribble di lingkungan SMP Negeri 1 Prigen yaitu peserta kegiatan ekstrakurikuler.

Oleh karena yang melatar belakangi permasalahan ini adalah tentang kelincahan dan keterampilan menggiring bola, maka penulis akan melakukan penelitian dengan judul "Pengaruh Latihan Kelincahan Dribble Bentuk T-Drill Langsung dan Tidak Langsung terhadap Peningkatan Kemampuan Keterampilan Dribble Bolabasket Peserta Kegiatan Ekstrakurikuler SMP Negeri 1 Prigen”. Tujuan penelitian ini adalah untuk mengkaji dan memperoleh informasi pengaruh latihan kelincahan dribble $T$-Drill langsung dan tidak langsung terhadap peningkatan kemampuan dribble bolabasket. Untuk mengkaji dan memperoleh informasi pengaruh latihan kelincahan dribble $T$-Drill langsung dan tidak langsung mana yang lebih baik terhadap peningkatan kemampuan keterampilan dribble bolabasket.

\section{METODE}

Penelitian ini menggunakan rancangan eksperimental bentuk Randomized Control Groub Pre test-Post test Design. Populasi dalam penelitian ini adalah peserta kegiatan ektrakurikuler bolabasket SMP Negeri 1 Prigen yang berjumlah 34 orang coba. Pengambilan sampel menggunakan teknik systematic porposive random sampling dengan presentase sebesar $90 \%$ dari 36 peserta, sehingga jumlah sampel 34 peserta perempuan. Adapan variabel yang terlibat dalam penelitian ini yaitu: (1). variabel bebas diantaranya adalah (a) latihan dribble bentuk $T$-Drill langsung (b) latihan dribble bentuk $T$-Drill tidak langsung, (2). variabel terikat berupa peningkatan kemampuam keterampilan dribble bolabasket, variabel kendali berupa (a) jenis kelamin, (b) latihan dribble latihan dribble agility T-Drill langsung dan tidak langsung, (c) peserta ekstrakurikuler bolabasket SMP Negeri 1 Prigen. Pembagian kelompok menggunakan teknik ordinal pairing, dalam setiap kelompok 
terdiri dari 17 peserta didik. Kelompok yang dilibatkan dalam penelitian ini terdiri dari dua kelompok, yaitu kelompok eksperimen dan kelompok kontrol (pembanding).

Instrumen penelitian ini menggunakan instrumen tes dan non tes. Tes yang digunakan berupa tes dribble bentuk $T$-drill langsung dan tidak langsung yang bertujuan untuk mengukur kelincahan, dan instrumen non tes yang diberikan adalah observasi pada saat latihan, wawancara kepada pelatih dan angket untuk peserta kegiatan ekstrakurikuler bolabasket. Dalam penelitian ini pengumpulan data dilakukan dengan teknik pengukuran bentuk tes yaitu tes keterampilan bentuk tes keterampilan olahraga berupa tes dribble $T$-test langsung dan tidak langsung,dan teknik observasi digunakan untuk mengamati pelaksanaan pengambilan data pada saat tes awal (pretest) dan tes akhir (posttest). Berdasarkan pada tujuan penelitian dan dengan pertimbangan jenis data yang terkumpul berupa data rasio, maka data analisis dengan statistika inferensial berupa analisi varian satu jalur (ANAVA), hipotesis menggunakan a sama dengan 0,05. Jika F $F_{\text {hitung }} 76,7334$

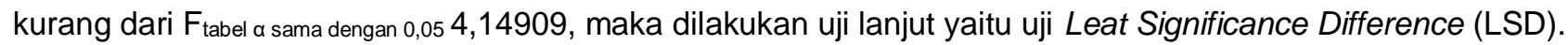

\section{HASIL}

Hasil uji normalitas penelitian ini menggunakan teknik Liliefors, hasil analisis tes awal kelompok latihan keterampilan dribble $T$-Drill langsung diperoleh hasil Lnitung 0,06905 kurang dari Ltabel a sama dengan 0,05 0,206 dan tes akhir Lhitung 0,0936 kurang dari Ltabel a sama dengan 0,05 0,206. Sedangkan tes awal kelompok latihan keterampilan dribble $T$-Drill tidak langsung diperoleh hasil Lhitung 0,0846 kurang dari Ltabel a sama dengan 0,05 0,206 dan tes akhir Lhitung 0,09010 kurang dari $L_{\text {tabel a sama dengan } 0,05} 0,206$. Berdasarkan hasil analisis data yang diperoleh dari masing-masing kelompok, maka disimpulkan bahwa tes awal dan tes akhir keterampilan passing bawah data menunjukkan berdistribusi normal.

Hasil homogenitas tes awal keterampilan dribble pada kelompok latihan dribble $T$-Drill langsung dan tidak langsung diperoleh hasil sebesar $F_{\text {hitung }} 1,202$ kurang dari $F_{\text {tabel a sama dengan } 0,05} 2,33$, dan hasil tes akhir kelompok latihan dribble $T$-Drill tidak langsung diperoleh hasil sebesar $F_{\text {hitung }} 0,995$ kurang dari $F_{\text {tabel a sama dengan } 0,05} 2,33$. Untuk mengetahui perbedaan antara sebelum dan sesudah perlakuan kelompok latihan dribble T-drill langsung diperoleh thitung 14,8087 dan tabel 1,746, dan kelompok latihan dribble $T$-Drill tidak langsung diperoleh thitung 9,9399 dan tabel 1,746. Untuk mengetahui pengaruh latihan dribble bentuk $T$-Drill langsung dan tidak langsung terhadap peningkatan kemampuan keterampilan dribble bolabasket diperoleh sebesar $F_{\text {hitung }}$ 76,73344 lebih dari $F_{\text {tabel a sama dengan } 0,05} 4,149097$, berarti ada perbedaan yang berhubungan tes kemampuan keterampilan dribble antara sebelum tes kemampuan keterampilan dribble kelincahan bentuk $T$-Drill langsung dan tidak langsung. Hasil analisis uji F dilanjutkan dengan menghitung uji lanjut bentuk Leat Significance Difference (LSD), hasil mean data seluruh kelompok diperoleh 5,61707 dan koefisien $\operatorname{LSD}_{0,05} 1,652$.

\section{PEMBAHASAN}

\section{Pembahasan Hasil Analisis Data tentang Pengaruh Latihan Dribble T-Drill Langsung terhadap Peningkatan Kemampuan Keterampilan Dribble Bolabasket Peserta Kegiatan Ekstrakurikuler}

Hasil analisis data menggunakan teknik uji-t sampel berhubungan telah ditemukan thitung 14,8087dan tabel 1,746 , oleh karena thitunglebih dari trabel a sama dengan 0,05 , berarti hipotesis nihil yang berbunyi tidak ada perbedaan kemampuan keterampilan dribble bolabasket antara sebelum dan sesudah latihan keterampilan dribble pada kelompok dribble $T$-Drill langsung dinyatakan ditolak dan hipotesis kerja yang menyatakan ada perbedaan kemampuan keterampilan dribble bolabasket antara sebelum dan sesudah latihan kelompok dribble T-Drill langsung diterima. Berarti ada perbedaan yang signifikan keterampilan dribble bolabasket antara sebelum dan sesudah latihan pada kelompok dribble T-Drill langsung. Terjadinya perbedaan kemampuan keterampilan dribble tersebut karena orang coba memperoleh rangsangan dari luar berupa latihan-latihan sesuai dengan program latihan yang dilakukan. Intensitas latihan didesain dua kali latihan tiap minggu selama 90 menit yang terdiri dari 15 menit pemanasan, 60 menit perlakuan dan 15 menit pendinginan menggunakan intensitas latihan $45 \%-55 \%$ setiap minggu selama enam minggu dapat ditetapkan untuk melihat ada tidaknya kemajuan keterampilan dribble pada peserta kegiatan ekstrakurikuler bolabasket SMP Negeri 1 Prigen Kabupaten Pasuruan. 
Dalam permainan bolabasket diperlukan adanya gerakan multi arah, artinya pergerakan tersebut bukan hanya linier. Oleh karena itu diperlukan adanya kemampuan untuk mengubah posisi tubuh kesegala arah yang berguna bagi peserta kegiatan ekstrakurikuler dalam menggiring bola dan menipu lawan sehingga peserta kegiatan ekstrakurikuler bisa mencetak angka. Untuk itu diperlukan adanya latihan yang dapat membantu dalam hal ini yakni latihan kelincahan.

Kombinasi antara two- and three-cone drill sangat baik untuk bekerja pada kualitas keseluruhan gerakan dan penguasaan teknik. Selain itu, latihan the star drill, attack and retreat drill, $T$-drill, dan pro-agility drill sangat bagus untuk meningkatkan kecepatan perubahan arah. Selain itu, pelatih dapat membuat modifikasi khusus olahraga untuk beberapa latihan ini. Seperti kebanyakan latihan ketangkasan, begitu atlet telah secara efisien mencapai gerakan berkualitas tinggi, pelatih dapat memperkenalkan isyarat pendengaran dan visual untuk meningkatkan kompleksitas (Gong \& Ning, 2016; Vieyra, 2016).

\section{Perbedaan Hasil Analisis Data tentang Pengaruh Latihan Dribble T-Drill Tidak Langsung terhadap Peningkatan Kemampuan Keterampilan Dribble Bolabasket}

Hasil analisis menggunakan teknik uji-t sampel berhubungan telah ditemukan thitung 9,9399dan tabel 1,746.Sehingga $H_{o}$ ditolak dan hipotesis kerja yang menyatakan ada perbedaan yang signifikan antara sebelum dan sesudah latihan $T$-Drill tidak langsung terhadap kemampuan keterampilan dribble bolabasket. Berarti thitung lebih dari tabel a sama dengan 0,05, ada perbedaan antara sebelum dan sesudah latihan dribble T-Drill tidak langsung diterima. Berarti latihan dribble T-Drill tidak langsung dapat meningkatkan kemampuan keterampilan dribble bolabasket. Terjadinya perbedaan kemampuan kelincahan bergerak dapat dilihat dari hasil tes yang telah dilakukan. Dari hasil tes awal dan tes akhir diperoleh hasil rata-rata skor tes awal 19,30 detik dan tes akhir 17,74 detik, skor tes akhir lebih baik dari pada tes awal. Selain itu latihan yang dilakukan dengan menggunakan latihan dribble $T$-Drill tidak langsung bentuk $T$-Drill dapat berdampak pada kemampuan keterampilan gerak dribble.

Latihan kelincahan memiliki beberapa komponen yaitu perlambatan yang mengacu pada kemampuan untuk mengurangi kecepatan atau berhenti dari kecepatan maksimal, keseimbangan merupakan kemampuan untuk mempertahankan kontrol atas tubuh saat bergerak, dan sistem energi yang dapat membantu kecepatan gerak (Spasic et al., 2015; Zemková \& Hamar, 2014). Maksud dari pendapat tersebut adalah sama halnya dengan latihan kelincahan dribble T-Drill langsung, kelompok latihan kelincahan dribble $T$-Drill tidak langsung merupakan latihan yang dapat meningkatkan kemampuan keterampilan bergerak, karena beberapa komponen dan ciri-ciri dari pendapat diatas sudah dapat dipenuhi dengan latihan keterampilan dribble.

Latihan dribble $T$-Drill tidak langsung sama dengan latihan dribble $T$-Drill langsung, yang membedakan adalah saat melakukan dribble T-Drill. Ciri dari perlakuan latihan kelincahan lambat adalah adanya gerakan yang dilakukan tidak langsung yaitu berputar satu kali ketika melewati tiap-tiap cone pada saat peserta berlari sambil menggring bola.Akan tetapi, karena gerakannya tidak langsung yaitu gerakan berputar $180^{\circ}$ di tiap-tiap cone tengah tersebut berdampak pada tidak cepat atau kurang optimalnya gerakan yang dilakukan.

Latihan memiliki tiga bagian: diantaranya adalah crossover dribble, dribble ke belakang (behind-the-back dribble) dan retreat and crossover dribble. Menggiring bola dilakukan dengan kecepatan penuh selama setiap bagian latihan. (1) crossoverdribble: dimulai dari kerucut dasar. Menggiring bola dilakukan dengan kecepatan penuh dengan tangan yang kuat. Setelah melewati kerucut kedua, buat crossover dribble dan alihkan bola ke tangan yang lemah. Kecepatan dribble dengan tangan menggunakan tangan yang lemah sampai melewati kerucut berikutnya. Lakukan kembali crossover dribble ke tangan yang kuat. Selanjutnya lakukan cara ini ke baseline yang berlawanan. Berbalik dan menggiring bola kembali ke kerucut yang pertama, lakukan crossoverdribble dan berpindah tangan saat Anda melewati setiap kerucut. (2) Behind-the-back dribble:Pada bagian ini latihan dilakukan dengan cara yang sama kecuali Anda membuat kecepatan penuh di belakang menggiring bola setelah Anda melewati setiap kerucut. (3) Retreat and crossover dribble. Kecepatan dribble bola ke kerucut pertama. melakukan dribblemundur, mengambil setidaknya tiga dribble kembali. Melakukan crossover dribble, dan kemudian melanjutkan dribble dengan cepat menuju ke kerucut berikutnya. Dilanjutkan dengan cara ini ke garis awal dan garis belakang yang berlawanan (dos Santos et al., 2017; Li et al., 2018). 


\section{Pembahasan Hasil Analisis Data tentang Pengaruh Diantara Latihan Dribble T-Drill Langsung dan Tidak Langsung terhadap Peningkatan Keterampilan Dribble Bolabasket Peserta Kegiatan Ekstrakurikuler}

Berdasarkan sajian data hasil anava uji $F$ diperoleh $F_{\text {hitung }} 33,10015$ dan $F_{\text {tabel }} 4,199097$, maka hipotesis nihil yang menyatakan tidak ada pengaruh kemampuan gerak ketrampilan dribble akibat latihan keterampilan dribble $T$-Drill langsung dan tidak langsung bentuk $T$-Test ditolak. Berarti ada pengaruh yang signifikan antara latihan keterampilan dribble T-Drill langsung dan tidak langsung bentuk T-Test terhadap pengaruh peningkatan kemampuan gerak keterampilan akibat latihan dribble T-Drill langsung dan tidak langsung diterima.

Ditinjau dari dan hasil analisis deskripsi tentang rata-rata hitung kemampuan keterampilan dribble bolabasket pada kelompok latihan dribble $T$-Drill langsung diperoleh rata-rata hitung tes awal 19,19 detik dan tes akhir 16,09 detik maka selisihnya sebesar 3,1 detik, sedangkan hasil rata-rata hitung kelompok latihan dribble $T$ Drill tidak langsung tes awal 19,30 detik dan tes akhir 17,74 detik maka terdapat selisih sebesar 1,56 detik. Dengan hasil tersebut dapat diketahui bahwa latihan dribble $T$-Drill langsung lebih baik dari pada latihan dribble T-Drill tidak langsung terhadap peningkatan kemampuan keterampilan bergerak.

Permainan bolabasket membutuhkan kombinasi gerak keterampilan, kecepatan, kelincahan yang digunakan untuk menggiring bola, mengoper, menangkap, melompat, menembak dan berlari kesegala arah (Afrilliyan et al., 2018; Chen et al., 2020). Hal ini menjelaskan bahwa komponen fisik salah satu aspek yang penting untuk meningkatkan kualitas atlet. Penempatan tiga kun diatur dalam garis lurus, dengan masing-masing kerucut 5 meter $(5 \mathrm{~m})$ terpisah dari yang berikutnya. Ini merupakan kerucut 2, 3 dan 4 . Kerucut keempat (kerucut 1) ditempatkan tegak lurus dengan kerucut 3 , sekitar 10 meter $(9 \mathrm{~m})$ jauhnya. Mulai dari kerucut 1 , atlet berlari ke kerucut 3, memotong ke kiri, dan kemudian berlari ke kerucut 2. Dengan menggunakan langkah-langkah pendek dan berombak, atlet melakukan putaran 180 derajat di sekitar kerucut 2, dan kemudian berlari ke kerucut 4. Kemudian melakukan 180 derajat berbalik kerucut 4 dan berlari kembali ke kerucut 3.Dan memotong ke kiri dan kemudian mempercepat melewati kerucut awal.Pola $T$ pada latihan $T$-Drill merupakan latihan yang baik digunakan untuk mengembangkan percepatan, deselerasi, dan perubahan arah ledakan yang cepat (Kaplan, 2016; Zhang, 2015).

\section{KESIMPULAN}

Berdasarkan pada rumusan masalah dalam bab I, hasil analisis data dan mengacu pada pengujian hipotesis, maka penelitian dapat disimpulkan sebagai berikut: (1) ada perbedaan antara sebelum dan sesudah latihan dribble bentuk agility $T$-Drill langsung terhadap peningkatan kemampuan keterampilan dribble peserta kegiatan ekstrakurikuler bolabasket SMP Negeri 1 Prigen, (2) ada perbedaan antara sebelum dan sesudah latihan dribble bentuk agility $T$-Drill tidak langsung terhadap peningkatan kemampuan keterampilan dribble peserta kegiatan ekstrakurikuler bolabasket SMP Negeri 1 Prigen, dan (3) terdapat pengaruh latihan dribble bentuk agility $T$-Drill langsung dan tidak langsung terhadap kemampuan keterampilan dribble bolabasket. Latihan diebble bentuk agility T-Drill langsung lebih baik dibandngkan dengan latihan dribble bentuk agility $T$ Drill tidak langsung terhadap peningkatan kemampuan keterampilan dribble peserta ekstrakurikuler bolabasket SMP Negeri 1 Prigen.

\section{DAFTAR PUSTAKA}

Adiningtyas, W. P., Tomi, A., \& Yudasmara, D. S. (2020). Survei Pembinaan Ekstrakurikuler Bolabasket pada Peserta Didik Sekolah Menengah Atas. Sport Science and Health, 2(1), 32-38. http://journal2.um.ac.id/index.php/jfik/article/view/11129/5120

Afrilliyan, A., Pramono, H., \& Soenyoto, T. (2018). The Effects of Exercise and Agility on Dribble (Skills) of Basketball Extracurricular Participants in SMPN 10 Bengkulu Article Info. Journal of Physical Education and Sports JPES Unnes, 7(1), 83-87. https://journal.unnes.ac.id/sju/index.php/jpes/article/view/23442

Arshi, A. R., Nabavi, H., Mehdizadeh, S., \& Davids, K. (2015). An alternative approach to describing agility in sports through establishment of a relationship between velocity and radius of curvature. Journal of Sports Sciences, 33(13), 1349-1355. https://doi.org/10.1080/02640414.2014.990481 
Chen, W. H., Yang, W. W., Lee, Y. H., Wu, H. J., Huang, C. F., \& Liu, C. (2020). Acute Effects of Battle Rope Exercise on Performance, Blood Lactate Levels, Perceived Exertion, and Muscle Soreness in Collegiate Basketball Players. Journal of Strength and Conditioning Research, 34(10), 2857-2866. https://doi.org/10.1519/JSC.0000000000002661

Department for Education. (2013). Physical education programmes of study: key stages 3 and 4 National curriculum in England Purpose of study. London: DfE, 1-3. https://www.gov.uk/government/uploads/system/uploads/attachment_data/file/239086/SECONDARY_ national_curriculum_-_Physical_education.pdf

dos Santos, P. P., de Souza, G. C., Alves, D. L., Rodacki, A. L. F., Lima-Silva, A. E., \& De-Oliveira, F. R. (2017). Physiological demands of wheelchair basketball. Journal of Exercise Physiology Online, 20(5), $52-59$.

Education, P., Hills, R., \& Pradesh, A. (2016). Comparative Study On Emotional Intelligence Among General Education , Physical Education And Athletes. International Education \& Research Journal, 2(10), 74 77.

Eom, S. Y., Lee, W. J., Lee, J. II, Lee, E. H., Lee, H. Y., \& Chung, E. J. (2014). The effect of ankle Kinesio taping on range of motion and agility during exercise in university students. Physical Therapy Rehabilitation Science, 3(1), 63-68. https://doi.org/10.14474/ptrs.2014.3.1.63

French, K. E., \& Thomas, J. R. (2016). The Relation off Knowledge Development to Children's Basketball Performance. Journal of Sport Psychology. https://doi.org/10.1123/jsp.9.1.15

Gong, C., \& Ning, C. (2016). Motion simulation in a virtual basketball shooting teaching system. International Journal of Online Engineering, 12(2), 55-57. https://doi.org/10.3991/ijoe.v12i02.5049

Hayashi, C. T. (2016). Foundations of Sport and Exercise Psychology. Journal of Sport and Exercise Psychology, 20(3), 336-338. https://doi.org/10.1123/jsep.20.3.336

Kaplan, T. A. (2016). A Case for Basketball in Health-Related Physical Activity, Education, and Research. Pediatric Exercise Science, 7(2), 121-126. https://doi.org/10.1123/pes.7.2.121

Li, Y., Yao, M., Zhou, Q., Cheng, Y., Che, L., Xu, J., Xiao, J., Shen, Z., \& Bei, Y. (2018). Dynamic regulation of circulating microRNAs during acute exercise and long-term exercise training in basketball athletes. Frontiers in Physiology, 9(MAR). https://doi.org/10.3389/fphys.2018.00282

Markula, P. (2015). Assessing the sociology of sport: On sport and exercise. International Review for the Sociology of Sport, 50(4-5), 536-541. https://doi.org/10.1177/1012690214539958

Mclnnes, K. A., Younger, A. S. E., \& Oxland, T. R. (2014). Initial instability in total ankle replacement: A cadaveric biomechanical investigation of the star and agility prostheses. Journal of Bone and Joint Surgery - American Volume, 96(17), e147.1-e147.8. https://doi.org/10.2106/JBJS.L.01690

Mehdizadeh, S., Arshi, A. R., \& Davids, K. (2015). A minimal limit-cycle model to profile movement patterns of individuals during agility drill performance: Effects of skill level. Human Movement Science, 41, 207217. https://doi.org/10.1016/j.humov.2015.03.009

Puente, C., Abián-Vicén, J., Salinero, J. J., Lara, B., Areces, F., \& Del Coso, J. (2017). Caffeine improves basketball performance in experienced basketball players. Nutrients, 9(9). https://doi.org/10.3390/nu9091033

Rohmatunisha, S., Wahyudi, U., \& Yudasmara, D. S. (2020). Survei Minat Siswa dalam Mengikuti Kegiatan Ekstrakurikuler Bolabasket pada Peserta Sekolah Menengah Pertama. Sport Science and Health, 2(2), 119-129. http://journal2.um.ac.id/index.php/jik/article/view/11266/5286

Sciences, S. (2014). Zihinsel Engelli Bireylerde Sporun Etkilerine Yönelik Farkındalık Ölçeği (ZEBSEYFÖ) Geliştirme Çalışması. CBÜ Beden Eğitimi ve Spor Bilimleri Dergisi, 9(1), 19-36.

Society of Health and Physical Educators America. (2016). Status of physical education in the USA. In Shape of the Nation. www.shapeamerica.org/shapeofthenation.\%0APURPOSE

Spasic, M., Krolo, A., Zenic, N., Delextrat, A., \& Sekulic, D. (2015). Reactive agility performance in handball; 
development and evaluation of a sport-specific measurement protocol. Journal of Sports Science and Medicine.

Sport England. (2015). Once a week participation in sport. Active People Survey, October 2013, 2013-2015. https://www.sportengland.org/media/3783/1x30_overall_factsheet_aps9v2.pdf

Stöckel, T., \& Vater, C. (2014). Hand preference patterns in expert basketball players: Interrelations between basketball-specific and everyday life behavior. Human Movement Science, 38, 143-151. https://doi.org/10.1016/j.humov.2014.09.002

Stovern, O., Henning, C., Porcari, J. P., Doberstein, S., Emineth, K., Arney, B. E., \& Foster, C. (2019). The Effect of Training with a Foam Roller on Ankle and Knee Range of Motion, Hamstring Flexibility, Agility, and Vertical Jump Height. Int J Res Ex Phys, 15(1), 39-49. https://ijrep.org/wp-content/uploads/lanadownloads/2020/01/stovern.et_.al_.fall_.2019.pdf

Trojian, T. H., Cracco, A., Hall, M., Mascaro, M., Aerni, G., \& Ragle, R. (2013). Basketball injuries: Caring for a basketball team. Current Sports Medicine Reports. https://doi.org/10.1097/01.CSMR.0000434055.36042.cd

Vieyra, F. (2016). Pickup Basketball in the Production of Black Community. Qualitative Sociology, 39(2), 101123. https://doi.org/10.1007/s11133-016-9324-9

W. Kusnanik, N., Widiyanto, W. E., \& P. Bird, S. (2019). Effect of Reactive Agility Training Drills on Speed and Agility in Indonesian University Students. The Journal of Social Sciences Research, 58, 1272-1275. https://doi.org/10.32861/jssr.58.1272.1275

Winslade, M., \& Wright, B. (2019). Sport and exercise. In Wellbeing in Higher Education (pp. 120-132). https://doi.org/10.4324/9781315641539-12

Zemková, E., \& Hamar, D. (2014). Agility performance in athletes of different sport specializations. Acta Gymnica, 44(3), 133-140. https://doi.org/10.5507/ag.2014.013

Zhang, Y. (2015). Research on the improving effect of the compound beverage on the sports capacity of basketball athletes. Advance Journal of Food Science and Technology, 8(7), 480-482. https://doi.org/10.19026/ajfst.8.1549 